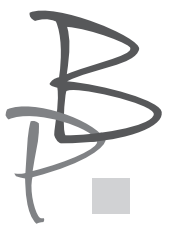

Kateryna Khomenko*

Odeskie Muzeum Literatury, Ukraina

https://orcid.org/0000-0001-5999-460X

\title{
Литературный миф Одессы в малоизвестных текстах XIX века
}

\author{
Odessa's literary myth in little-known texts \\ of the XIX century
}

Abstract: The article is devoted to the origin of the Odessa myth. Odessa is compared to little Paris and Italy. Sometimes it is called South Palmyra. The city is known far beyond the borders of Ukraine. Is Odessa really a beautiful Palmyra? The origin of the "Odessa myth" coincides with the foundation of the city and distills the city itself in the speed of development. The rumor about the city is spread in Chumak songs, which speak of how to live freely in the city or the foundation upon which Odessa could be a liberal city. One of the most striking literary images of Odessa was created by A.S. Pushkin, but by no means is it the only one. The article provides unpublished or inaccessible texts of the first half of the XIX century about Odessa. In the memoirs of travelers the "otherness" and "features" of Odessa are noted. At the same time, 
they describe completely ordinary things, such as citizens, places, and the dust in the streets. Fragments of rare texts by I. Dolgoruky, K. Batyushkov, N. Chizhov, M. Rosberg, E. Gan-Fadeev, O. Chizhevich, A. Deribas are given. .

Keywords: Odessa, memoirs, the literature portrait of Odessa, beginning of nineteen century, inspiration, Odessa myth.

Одесский миф возник с рождением города. О нем писали в статьях в конце XX века разные одесские краеведы-исследователи: Марк Найдорф, Евгений Голубовский, Борис Херсонский, Борис Владимирский, Елена Каракина. Эта тема привлекала и зарубежных исследователей славистов из Германии, Соединенных Штатов Америки, Голландии, Израиля и Польши. Этот миф рассматривается в книге участника конференции Ярослава Полищука „Фронтирна ідентичність: Одеса XX століття”.

В литературу „Одесский миф” вошел после публикации одесской главы Евгения Онегина. Пушкин создал самый известный литературный образ города и одновременно миф о нем. Согласно видению Пушкина, Одесса была европейским городом с пестрым многоязычным населением, театром, оживленной торговлей. Пушкин пишет и об отрицательных сторонах Одессы: пыль, проблемы с водой, мало деревьев.

Во всех - и более ранних, и более поздних - текстах первой половины XIX века присутствует хотя бы одна из этих черт. Во всех текстах прослеживается даже не просто знакомство авторов, а особо пристальное внимание к деталям, на которые ранее обратил внимание Пушкин.

Одесса позиционировалась как иностранный город на территории Российской Империи. Князь Иван Долгорукий писал в 1810 году:

Уехал бы в Париж, потому что люблю шум, гам, театр, роскошь и прочее, и прочее; а где всего этого более, как не во Франции? Но у кого нет ни вотчины денег, тот живет, как Бог велит. Мне вздумалось проехаться: все дома да дома, наскучит и мудрецу. Общая молва, журналы, ведомости мне 
вскружили воображение. Я решился и поехал с женою и четырьмя домашними товарищами в Одессу1.

Подлинно не известно, о каких именно журналах пишет Долгорукий. Возможно это петербургский журнал „Лицей”, где в 1806 году впервые было опубликовано стихотворение П.Ф.Б. „Одесса”:

Там ныне здания огромные явились,

Обилие во всем и вкус и красота

Народы разных вер и стран там водворились.

где дикия места, где делась пустота?²

Спустя 8 лет Долгорукому вторит поэт Константин Батюшков в одном из своих писем: „Письмо Ваше я получил в Одессе, или в русской Италии... Одесса приятный город. Море здесь как море и намного приятнее ледяного залива Финского” в другом письме 1818 года „Одесса - чудесный город, составленный из всех наций в мире, и наводнен итальянцами [...] Коммерция его создала и питает..."з

Предметом этого материала являются малоизвестные непереизданные или переизданные малым тиражом тексты об Одессе. Малодоступные для исследователей, которые непосредственно не живут и не работают в Одессе. Это воспоминания путешественников, воспоминания одесситов, художественные произведения.

Одно из первых описаний, сделанных профессиональным литератором, оставил князь Иван Михайлович Долгорукий (1764-1823) - тайный советник, потомок основателя Москвы, поэт, прозаик, драматург. Один из образованнейших людей своего времени. Бывал в Одессе несколько раз. Полное название книги о поездке в южные губернии России „Славны бубны за горами, или Путешествие мое кое-куда 1810 года”. Закончил

1 И. М. Долгорукий, Славны бубны за горами, или мое путешествие кое-куда 1810года, [w:] Южная столииа: Одесса первой половины XIX века в литературных и краеведческих источниках, мемуарах, дневниках, письмах, red. Г.В. Закипная, Т. И. Липтуга, Одесса-Москва 2009, s. 21.

2 П.Ф.Б., Oдесca [w:] tamże, s. 15.

3 К.Н. Батюшков, Из писем Батюшкова К.Н., [w:] tamże, s. 53. 
книгу Долгорукий уже после выхода в отставку в 1812 году, опубликована она была в 1869 году в Москве. Фрагменты из книги публиковались в сборнике „Одесская старина” в 2006 году и в дорогом подарочном издании Южная Столица в 2009 году.

Иван Михайлович рисует уклад жизни города, поведение жителей, которые ему не всегда приятны и понятны. Одесса уже успела обрасти легендами, некоторые Долгорукий печально опровергает. Например, об апельсинах „боялся даже, что уеду из Одессы, не евши апельсинов”. О генерал-губернаторе Новороссии и Бессарабии (1804-1815) французском аристократе Армане Эммануэле дю Плесси Герцоге де Ришелье: „Дюк 4 любит преимущественно водиться с купечеством, сравнивает его с собою и не редко сажает выше чиновника гражданского самого незначащего купчишку. Для чего не покровительствовать этому состоянию? Но все имеет свои границы”5.

Повторим еще раз все выгоды этого прославленного края: никакого общества, все сидят по домам и живут из барыша. С расчетом жить во время торговли - найдешь себя в обетованной земле; но для удовольствия еще рано сюда переселяться: скверная квартира 50 руб. в месяц; четверня лошадей 10 руб. в сутки; ни полена дров, топи кизиком, от которого воняет; пыль, мухи, зной, или холодный ветер: какая мука!

Итак, отложа всякое пристрастие, не станем заблуждаться и согласимся, что Одесса, по недавнему своему образованию, очень хороша, но что она еще ни в сотую долю не доведена до того степени превосходства во всех частях, до какого назначает ей сама натура и ее точка во вселенной, и долго еще об ней хвастать надобно будет в журналах, чтоб заманить туда любопытного.

Долгорукий писал: „Одесса выстроена камнем. Известно, что тут была прежде у турок неважная крепостца, называемая Гаджибей: теперь

4 «Дюк» с фр. герцог. В Одессе употребляется по отношению к генерал-губернатору Новороссии и Бессарабии (1804-1815) французскому аристократу Арману Эммануэлю дю Плесси герцогу де Ришелье (1766-1822).

5 К. Н. Батюшков, Из писем Батюшкова К.H., dz. cyt., s. 53. 
вы тут насчитаете домов до 200 каменных [...] и ни одного строения деревянного в целом городе”6. Обратившись к теме одесских катакомб, которые ни по происхождению и ни по использованию катакомбами не являются, Долгорукий не перестает удивляеться Одессе:

...вид города умерил восторги; ибо он издали неказист и на горе до него 18 верст объезда круг моря. Для всех тех, кои привыкли к Русским городам, всякий иностранный (и Одесса строится, думаю, на манер такой же) покажется с виду нехорош. У нас, что красит города и даже многие села? Церкви, колокольни и башни: где ж их нет? а во многих несколько. Что до этого, что внутри нищета! но Пономарь звонит, издали видишь шпиц, уши и глаза пленяются, и путешественник кричит: «Ах! какой славный город!» В Одессе церквей мало, колоколен нет, ни что не выходит из кучи равного строения; и так первый на нее взгляд не обворожает.

Внутри города в редком доме можно найти спокойное убежище. Если не палит зной, от которого иные охраняют себя красивыми шторами в окнах, то страшная пыль по улицам поднимается столбом и вселяется облаками в вашу комнату, потому что редкий день не ветрено в Одессе; или не сказанная тьма мошек и мух одолеют вас так, что без махалки ни за что приняться нельзя. Вот самое беспокойное неудобство здешнего места! Я видывал во многих домах среди лета, в самые жаркие его дни, двойные оконины еще вмазанные для того, чтоб не впустить в комнаты солнца, мух и пыли; и так никто здесь не живет прежде ночи: жарко, душно, пыльно! Всякий обыватель должен здесь запастись всем для него нужным, иначе он ничего себе не достанет, ниже сливок, и для путешественника это очень тягостно; телятины вовсе нет, плодов никаких, кроме кислых вишен. Оранжерей ни у кого нет: всякий ждет плодов от натуры на вольном воздухе, и получает их не очень много ранее наших садов, а всегда позже Северных оранжерей. Прошу за эту статью прощения у всех любителей тамошних насаждений, но право я ничего в этом роде не нашел, ни в садах, ни в погребах, среди июля, для прихоти и вкуса; боялся даже, что уеду из Одессы, не евши апельсинов, но, к крайнему моему счастью, как-то нечаянно залетело

6 И. М. Долгорукий, Славны бубны за горами, или мое путешествие кое-куда 1810 года, [w:] tamże, s. 23. 
какое-то чужеземное судно, которое привезло в Одессу несколько тысяч апельсинов, и я, через знакомых моих, достал их до ста, кои увез с собою. Они были толстокоры, не довольно еще зрелы, но видно было, что не лежалые, как те, кои у Троицы под горой покупаем мы так часто за самые дорогие деньги с зелеными пятнами.

Все заморские товары чрезвычайно дороги были. Сахар продавался по 2 руб. фунт, и кофе также. Дров почти нет; многие, или лучше сказать, почти все жгут на кухне кизик, и тот почитается зажиточным хозяином, у кого его много. Кизик называется земляным кирпичом, потому, думаю, что он такой же формы и меры режется, и когда продается хутор, или дача, то в опись имения входит и кизик.[...]

[...] Одесса может хвастать своим городским Лазаретом: я до сих пор нигде не видал такого хорошего. Он построен от города; залы для помещения больных превеликие, человек до ста в одной уложить можно; все средства к очищению воздуха приняты; за то и можно гулять по тамошней больнице, как в самой чистой большого барина зале: ни что не оскорбляет ни взора, ни обоняния. Распорядок ее основателен и все необходимости столь полезного заведения удовлетворены.

Мне показывали в больнице карету, сделанную нарочно для купанья: она закладывается в одну лошадь сзади и спереди. В ней можно въехать в море, и выехать из него свободно. Польза выдумки, думаю, в том, что дама может одеться и раздеться самым скрытным образом. Но это недостаточно: какая женщина захочет в виду всего города погрузиться в море и нырять в нем, как Наяда? Кроме непристойности, зной прожжет череп; море открыто, отмели зелены и зловонны; надобно далеко объезжать и искать чистого берега для плаванья. Нигде купальни нет, ни ванны закрытой; следовательно, всякой любопытный может смотреть на вас в самую нечаянную минуту; от этого, думаю, и карета без употребления, и дамы, да и мужчины, многие не купаются.

Лекари говорят, будто садиться в море очень здорово. Я в одно утро собрался было попробовать этой пользы, и пошел по скалам узенькой тропинкой. Слуга передо мною нес стул и нужные вещи: стул из рук его сорвался и полетел до края моря с высокой горы без остановки; я шествовал за ним по крутому камню и, взглянувши на пропасть, в которую полетел стул, отложил намерение поверять на себе докторскую систему. Долго ли 
потерять равновесие? Тут можно тысячу смертей найти в рытвинах между гор прежде нежели достигнуть тех мест, где утопиться опасно.

[...] Многие богатые купцы, особливо Греки, очень скупы, имеют свои конторы, но сами редко живут при них, а насылают приказчиков, кои не в праве роскошничать, берегут деньги и копят их; следовательно, город не ожитворен, а может быть он мне показался скучен и потому, что в летнюю пору все из городов бегут в поле. Иные имеют хутора, и разводят при них сады. В публичных местах нигде при мне не было никакого съезда: все сидят по домам, выкладывают, считают и сулят жить для других тогда, как денег наживут больше; словом, всякий в Одессе дышит из барыша.

Правда, что в Одессе самой нег еще роскоши столичных городов, при всей изящности ее местоположения, но повторю еще раз, и с удовольствием, что натура вокруг ее все дала изобретательному человеку: почва плодоносная, природа ни у кого не остается в долгу; был бы труд и семя для посеяний. Хозяин самого небольшого хутора может величайший приобресть доход земляной работой. Солнце греет, роса живит, море прохлаждает... ${ }^{7}$

Это впечатления путешественников, побывавших в Одессе. А вот Одесса глазами местного жителя.

Михаил Петрович Розберг (1804 - 1874) - русский литератор, журналист. Жил в Одессе в 1830 - 1835 гг,, занимался педагогической и литературной деятельностью. М. П. Розберг редактировал газету „Одесский вестник” на русском и французском языках (1831 - 1833), издавал приложение к газете „Литературные листки” (1833 - 1834). „Письмо из Одессы к***” 1830 года адресовано поэму Теплякову В. Г. Впервые оно было опубликовано в „Одесский альманах на 1831 год”:

[...] вы уже почти в Одессе, у самой подошвы горы, которая, как огромный пьедестал, поддерживает этот величавый памятник, воздвигнутый гением торговли и силою России. Если хотите, чтобы Одесса сделала на вас с первого взгляда приятное впечатление, не приезжайте сюда ни осенью, ни весною, и выберите погоду тихую: в противном случае, Одесса покажется вам омутом грязи и пыли. Пушкин уже давно воспел одесскую грязь 
прекрасными стихами; этот предмет здесь до сих пор еще неистощим, но я не стану тебе говорить о нем, ибо все, что мог бы сказать, ты почтешь грубою выдумкой... В мае месяце сирень роскошно цветет в Городском саду, листья ярко зеленеют; в июле все уже сожжено солнцем, все запылено, и белые акации одесских бульваров становятся довольно похожи на эти березки, которые в Москве забывают убирать с тротуаров через несколько дней после Семика или Троицына дня. Одесса усеяна обширными каменными зданиями, но стены сих зданий так скудельны, что сильные порывы осеннего ветра заставляют их дрожать: это происходит от чрезвычайной рыхлости и легкости камня, употребляемого на постройку большей части домов, и состоящего из мелких раковин, слепленных между собою.

Сначала Одесса кажется весьма разнообразна, но скоро присматриваешься к этому разнообразию, и оно превращается в однообразие довольно утомительное: везде встречаешь те же лица, тех же людей, и заседания высшего круга здешнего общества, переходя в разные дни недели из дома в дом, только переменяют место и председателя, нимало не изменяясь в своем составе: куда ни явитесь - в церковь, в театр, на бал; в дни гулянья на бульвар, в Городской сад - везде встречаете всех и все...

В России издавна привыкли думать, что присутствие множества иностранцев наводит на общественную жизнь в Одессе какой-то особенный цвет. - Я этого не заметил; по крайней мере, в отношении к высшему кругу такое мнение совершенно несправедливо: ... главное удовольствие состоит в том, чтобы вместе поскучать; общительности, собственно, нет, но есть все, чем стараются заменить ее: есть кадрили, мазурки, котильоны, карты, лотереи. Из негоциантов только немногие являются на здешних званых вечерах и, не составляя значительной вклады в массе целого, не придают ей собою никакого резкого оттенка.

Если жизнь внутреннего человека здесь не получила еще всего объема, какой она имеет во Франции, Англии и Германии, зато внешняя достигла блистательной степени совершенства: образованность, утонченность вкуса одесских жителей высшего круга можно поставить в пример. Кто был на маскарадном бале, данном прошлогоднею зимою, на Масленице, графом М.С. Воронцовым, тот подтвердит справедливость слов моих. В этот вечер легко было представить себя перенесенным с берегов Черного моря не 
только в одну из столиц Европы, но в какой-то очаровательный, волшебный мир.

Самое лучшее время для прогулки в Одессе - вечер: солнце мало-помалу начинает заходить, последние лучи его алым сиянием обливают стоящие на рейде суда, которые тогда кажутся светлыми фонарями, зыблющимися на тихих водах; море превращается в золотой ковер, испещренный лазурными, розовыми, изумрудными узорами, и к берегам играет перламутром. Но очарование тогда только становится полным, когда взойдет оранжевая южная луна, и яркий, искристый столб от ее сияния засветится в темно-голубых волнах. Месячные ночи здесь особенно прелестны: луна на Юге не серебряная, как на Севере, а золотая, и действительно родная сестра солнцу: лучи ее не только светят, но будто заключают в себе какую-то животворную, если можно так выразиться, свежую теплоту ${ }^{8}$.

Составной частью „одесского мифа” является миф о прелести и образованности одесских женщин. Одним из подтверждений этого служит творчество Елены Ган-Фадеевой.

Ган-Фадеева Елена Андреевна (1814 - 1842) - писательница, „русская Жорж Санд”, по словам Виссариона Белинского. Она печаталась под псевдонимом „Зенеида Р-ва”. Ее дочери - писательница Вера Желиховская и антропософ и мистик Елена Блаватская - впоследствии далеко опередили мать по своей известности.

Отрывок из ее повести Теофания Аббиаджио (1840г):

Там громады зданий, тротуары, балконы, пестрые вывески гостиниц и мод. Там деревья, растущие будто нехотя вдоль улиц, блекнут под слоями белой известковой пыли, которая, вздымаясь в воздухе густыми облаками своими, при малейшем дуновении ветра занимает дыхание и въедается в глаза. Там голова кружится от смеси грохота экипажей по мостовой, визга немазаных колес под пирамидальными арбами угольщиков и воловьими подводами поставщиков пшеницы. Там выкиньте из головы все мысли, запрячьте подальше всякое чувство, чтобы, отразившись на лице, они не сделали вас смешным, скорее принимайте вид рассеянного far niente -

8 М. П. Розберг, Письмо из Одессы к***, [w:] tamże, s. 186. 
заимствуйте его хоть от этого сына юга и неги, который, полулежа на крыльце casino, блаженствует в полудремоте, не выпуская изо рта погасшей сигары. Там можно пройти полгорода, не встретив русского слова. Итальянский, французский, польский, греческий - вся эта смесь языков коснется вашего слуха, кроме языка русского, и, однако ж, вы в России. Разве случайно вам попадется толпа бородачей, которые, возвращаясь с работы, с пилами за плечами и апельсином в руках, толкуют меж собой: „Всем бы хорош городок Одесса, да нехристей в ней столько шатается, что Боже упаси"9.

С юмором и любовью описывает даже существенные недостатки Осип Чижевич (Осип Осипович Чижевич (1826-1898) - одесский общественный деятель, мемуарист. В 1846 г. закончил Ришельевский лицей. Служил в канцелярии генерал-губернатора, был членом комитета по делу об освобождении крестьян Тираспольского уезда от крепостной зависимости, многолетним членом городской управы Одессы). „Город Одесса и одесское общество (воспоминания старожила)" Чижевича никогда полностью не переиздавался, а отрывки встречаются в разных краеведческих сборниках, а также в интернете без ссылок на авторство. Его воспоминания являются источником анекдотов, городских легенд. Многие одесские экскурсоводы так или иначе цитируют фрагменты воспоминаний. Представляем некоторые фрагменты, изданные в 1879 году:

Памятник Дюка де Ришелье уже стоял на теперешнем месте. Возле него ежедневно скоплялась толпа приезжих мужиков-чумаков, считавших долгом пойти поглазеть на Дюка. Однажды в толпе нашелся грамотный остряк. На вопросы чумаков, почему это Дюк в левой руке, со стороны городского дома, в котором находились присутственные места, держит сверток бумаг, а правою рукою указывает на море, - остряк объяснил, что Дюк говорит: „Як маєш там судиться, то лучше в морі утопиться"10.

10 О. О. Чижевич, Город Одесса и одесское общество (Воспоминания одесского старожила), [w:] tamże, s. 387. 
Проблему с водой не оставил без внимания и Чижевич О.:

Водою город пользовался из многочисленных глубоких колодцев, устроенных на перекрестках улиц. Лучший колодец был Томилина, на Молдаванке. Лучшая вода добывалась из цистерн, устроенных при всех больших домах, в которые собиралась дождевая вода с крыш. Впоследствии построен был водопровод Ковалевского. Лучшею водою для питья, стирки и чая считалась цистерновая. Остальная имела солоноватый вкус. Воду развозили по домам водовозы. Обыкновенная цена на воду была от 3 до 5 коп. за пару ведер: но иногда доходила и до 20 коп. Однажды привезли воду из Николаева на пароходе» 11 .

Но вода оказалась „не фонтан”. Топографически точно описывает одесскую грязь:

На некоторых улицах в центре города незнакомому с местными ухабами, покрытыми грязью, нельзя было проехать без проводника. Я сам видел в конце Дерибасовской, против теперешней кондитерской Либмана, как выброшенный из опрокинувшихся дрожек господин в цилиндре попал в яму головою вниз и выскочил из нее, как из ванны, по шею в грязи. Там же, на Дерибасовской, для перехода через улицу появились носильщики из евреев, которые за гривенник переносили на спине прохожих. Близ Собора, против дома Папудова, на улице какой-то француз поставил паром и стоял на нем с удочкой в руках. В сочельник Рождества Христова ехавшие ко мне на кутью родные в карете попали в такой ухаб на Ришельевской улице, что карета сломалась, лошадей выпрягли, а дамы по колено в грязи вернулись домой пешком и остались без ужина.

На Канатной улице, близ дома Мешкова, в котором я квартировал, стояло такое озеро, что весною, во время перелета, я на нем стрелял бекасов. Самые высокие галоши не помогали. Пешеходы должны были носить высокие сапоги. Бывали случаи, что пьяный, упавший на улице, захлебывался и тонул в грязи.

11 Tamże, s. 389. 
Можно себе представить, что происходило в предместьях города. Молдаванка иногда прекращала сообщение с городом по целым неделям. Оно возобновлялось после сильных морозов, когда грязь замерзала.

Глубоко завязшие в грязи телеги и экипажи, захваченные морозом, иногда оставались на улицах в продолжении всей зимы, и только весною, при совершенной оттепели, могли быть извлечены ${ }^{12}$.

Далее Чижевич О. приводит описание отношение городских властей к проблеме:

Во время генерал-губернаторства графа Строганова ${ }^{13}$ одесские улицы были в самом безобразном виде. Грязь и ухабы на многих из них препятствовали движению экипажей, особенно в ночное время. Все жалобы начальству оставались без последствий. Сам граф ложился спать в 9 часов, а, если иногда и посещал театры, то проезжал по улицам, вполне исправным. Тогда придумали напустить на графа одну из одесских львиц, жену австрийского консула Ч-и, к которой и сам граф был неравнодушен. При первом свидании г-жа Ч-и сказала графу, что наши улицы до того ужасны, что по вечерам опасно выезжать из дому. На это граф прехладнокровно ответил: „Порядочные женщины по ночам сидят дома"14.

Сегодня самой популярной экскурсией в Одессе среди туристов разного возраста является так званая „Криминальная Одесса”. В Одессе успешно работает частный „Музей контрабанды”. Чижевич дает яркое описание функционирования одесских таможен и изобретательность контрабандистов:

Самая неприятная таможня была Херсонская, при надзирателе Зосиме Ивановиче Педашенко, малороссе, отличавшемся грубым обращением с проезжающими. В оправдание своего поведения 3.И. считал, что порядочные

12 Tamże, s. 390.

13 Александр Григорьевич Строганов (1795-1891) генерал-губернатор новороссийский и бессарабский (1854-1863), почетный гражданин Одессы.

14 Tamże, s. 392. 
люди старались обманным путем провезти контрабанду. В этом преступлении чаще всего попадались женщины. Например, одна спрятала под платьем маленькие стенные часы. К несчастью, во время осмотра часы стали бить, чем и выдали ее. Другая - подвесила куда-то целую головку сахара. В таможне шпагат оборвался, на пол из-под юбок выпала злополучная головка. Иногда попадались дамы, обмотавшие тело материей или кружевами. После таких проделок Зосим Иванович позволял себе без церемоний щупать толстых барынь, допрашивая: „А що сіє у вас натуральне, чи фальшивее"?

В числе разных ухищрений контрабандистов открыто было, что они переносили товары мимо таможни морем, на Пересыпи, в непромокаемых мешках, а чтобы скрыть себя получше от таможенной береговой стражи, шли по шею в воде, надевая на голову стальную плоскую шапку, походившую под цвет морской воды... 15

Невидимую черту, означающую конец одесского мифа XIX века и начало одесского мифа XX века, подводит внук родного брата, основателя Одессы, испанца Иосифа Дерибаса, писатель-краевед Александр Дерибас (1856-1937). Родился он и жил в Одессе. Учился в Императорском Новороссийском университете. Очерки Александра Дерибаса публиковались в газетах: „Правда”, „Одесские новости”, „Одесский листок” собраны в книгу Старая Одесса. Она переиздавалась несколько раз. Дерибас директором Одесской публичной библиотеки (1922-1924), а затем заведующим ее краеведческим отделом. Основанная им картотека и понятие „одессика” позже обогатятся произведениями создателей мифа Одессы $\mathrm{XX}$ века. 


\section{Literatura}

Атлас Д. Г., Старая Одесса, её друзья и недруги, Одесса 1992.

Дерибас А. М., Старая Одесса, Одесса 1990.

Полищук Я., Фронтирна ідентичність: Одеса ХХ століття, Київ 2019.

Пушкин А., Евгений Онегин, Москва 1981.

Южная столица: Одесса первой половины XIX века в литературных и краеведческих источниках, мемуарах, дневниках, письмах, ред. Г. В. Закипная, Т. И. Липтуга, Одесса-Москва 2009.

Найдорф М. И., Очерки европейского мифотворчества. Одесса 1999. Эл. ресурс: https://sites.google.com/site/marknaydorftexts/myth-making/3-ranniegody-odesskogo-mifa [dostęp: 03.07.2020 r.].

\section{Bibliografia}

Atlas D. G., Staraya Odessa, yeyo druz'ya i nedrugi, Odessa 1992.

Deribas A. M., Staraya Odessa, Odessa 1990.

Naydorf M. I., Ocherki yevropeyskogo mifotvorchestva. Odessa 1999. El. resurs: https://sites.google.com/site/marknaydorftexts/myth-making/3-rannie-godyodesskogo-mifa [dostęp: 03.07.2020 r.].

Polishchuk Y., Frontirna ídentichníst': Odesa XX stolíttya, Kiív 2019.

Pushkin A., Yevgeniy Onegin, Moskva 1981.

Yuzhnaya stolitsa: Odessa pervoy poloviny XIX veka $v$ literaturnykh $i$ krayevedcheskikh istochnikakh, memuarakh, dnevnikakh, pis'makh, red. G. V. Zakipnaya, T. I. Liptuga, Odessa-Moskva 2009. 